\title{
Integrated Coastal Management in Latin America: the ever New World ${ }^{*}$
}

\author{
Marinez Scherer ${ }^{\circledR}$, a; Monica F. Costa ${ }^{\text {b }}$ Tomasz Boski ${ }^{\text {c, }}$; Ulisses M. Azeiteiro $^{\text {e f }}$; João A. Dias ${ }^{\text {c, a }}$
}

\begin{abstract}
The advancement of Integrated Coastal Zone Management (ICZM) in Latin American countries may vary from established programs to experimental phase implementation and even inexistence. This creates an opportunity for the development of new ideas and experiments, especially in the quite long stretches of littoral where no occupation has yet been planned or consolidated. However there are localized issues that need to be attended with certain degree of urgency, especially in coastal settings that have been urbanized, developed for industry and/or are situated around port facilities. Spain and Portugal implemented the marine and environmental policies of European Union and may be seen as models for public and private ICZM initiatives. These situations created opportunities and needs that are somehow reflected in dedicated scientific production, as well as in social impact and the related capacity building programs. We surveyed some key costal management journals to know how Latin American based academics are doing in their mission of creating, developing and discussing ICZM along our diverse shores stretching along all climatic zones. Capacity building programs and exchange networks were also scrutinized. Results suggest that the thematic participation in the major publication channels is modest and needs to improve in number and diversity of subjects bringing obvious benefits to the policy and decision makers. Capacity building programs are still in its infancy across the region. There are no, or very few, specialized educational programs to form practitioners and scientists at all academic levels. Training programs integrating countries around all aspects of ICZM are even scarcer. Coordinated actions, such as networks across the political borders are one of the many future needs we point out here as being the next frontier for thinkers and managers in the region.
\end{abstract}

Keywords: South America; Coastal Governance; Capacity Building; Network

\section{RESUMO}

\section{Gestão Costeira Integrada na América Latina: o eterno Mundo Novo.}

A Gestão Integrada da Zona Costeira (GIZC) nos países da América Latina se encontra em diferentes níveis de desenvolvimento, desde programas estabelecidos, passando por níveis experimentais e pela não-existência de iniciativas de GIZC em alguns casos. Isso cria uma predisposição para o desenvolvimento de novas ideias e experiências, especialmente nos longos trechos de litoral, nos quais a ocupação ainda não foi planejada elou consolidada. Há, no entanto, questões localizadas que precisam ser atendidas de imediato, especialmente em ambientes costeiros que já foram urbanizados, industrializados ou

\footnotetext{
(a) Corresponding author to whom correspondence should be addressed: Romero <agatafr@gmail.com>

${ }^{a}$ Universidade Federal de Santa Catarina (UFSC), Centro de Filosofia e Ciências Humanas, Departamento de Geociências, Campus Universitário, Trindade, Florianópolis, SC, Brasil. E-mail: <marinezscherer@gmail.com>

${ }^{\mathrm{b}}$ Universidade Federal de Pernambuco (UFPE), Centro de Tecnologia e Geociências, Av. Prof. Moraes Rego, 1235, Cidade Universitária, Recife, PE, Brasil. E-mail: <mfc@ufpe.br>

c CIMA, Universidade do Algarve, Faculdade de Ciências e Tecnologia, Edifício 7, Campus Universitário de Gambelas 8005-139, Faro, Portugal. E-mail: <tboski@ualg.pt>

d Centro de Investigação Marinha e Ambiental (CIMA), Campus Universitário de Gambelas, Edifício 7, 8005-139 Faro, Portugal. E-mail: $<$ jdias@ualg.pt>

${ }^{\text {e }}$ CEF Universidade de Coimbra e Universidade Aberta (UAb), Departamento de Ciências e Tecnologia, 752 Rua do Ameal, 4200-055 Porto, Portugal. E-mail: <Ulisses.Azeiteiro@uab.pt>

f Centro de Ecologia Funcional, Departamento de Ciências da Vida, Universidade de Coimbra, 3000 • 456 Coimbra, Portugal.
}

\footnotetext{
* Submission: 26 DEC 2014; Peer review: 30 DEC 2014; Revised: 30 DEC 2014; Accepted: 31 DEC 2014; Available on-line: 2 JAN 2015
} 
ainda que se desenvolveram em torno de instalações portuárias. Espanha e Portugal - agora sob a influência da União Europeia - permanecem como nossos modelos de iniciativas de GIZC, tanto públicas quanto privadas. Estas oportunidades e necessidades de alguma forma refletem na produção local científica e seu impacto internacional, bem como em nossos programas de capacitação para a gestão integrada. Nós examinamos publicações de importância para gestão costeira a fim de averiguar como acadêmicos latino-americanos cumprem a sua missão de criar, desenvolver e discutir a GIZC. Analisamos também programas de capacitação e redes estabelecidas. As revistas mais representativas para a comunidade acadêmica de GIZC e que vem sendo publicadas pelo menos nos últimos 30 anos, e que foram brevemente examinadas nesta revisão foram a Ocean and Coastal Management, Coastal Management, Journal of Coastal Research e Journal of Coastal Conservation. Com relação aos programas de capacitação para a GIZC levou-se em consideração estudos recentes que demonstram que a maioria dos temas tratados nos cursos de pós-graduação acadêmicos relacionados com a GIZC não estão diretamente relacionadas com a gestão, mas sim às ciências natural, ou da terra, ou ainda à descrição da dinâmica costeira e ou poluição. Com apoio da Rede Ibero Americana de Gestão Costeira Integrada pode-se chegar a listagem de diversas redes que atuam na América Latina, Espanha e Portugal e que se relacionam com o tema. Os resultados sugerem que a representação nos principais veículos de publicação é tímido e precisa melhorar em número e diversidade de assuntos. Melhorias na publicação cientifica poderia levar a uma melhor utilização dos temas para o benefício dos tomadores de decisão. A capacitação também ainda está pouco desenvolvida na região. Existem poucos cursos especializados para formar técnicos e cientistas sobre o tema em níveis elevados de educação, ou nível de pós-graduação. Os programas de treinamento em torno de todos os aspectos da GIZC são ainda mais raros. A tendência em se considerar a perspectiva de integração como uma soma de conhecimentos disciplinares, não necessariamente ligados, são apresentadas em iniciativas de capacitação e produção científica. Esta abordagem é considerada falha pois, estas disciplinas, a maior parte do tempo, não se inter-relacionam para fornecer uma perspectiva holística para a gestão. Ações coordenadas, tais como redes, que ultrapassam as fronteiras políticas são uma das muitas necessidades futuras destacadas aqui como sendo a próxima fronteira para os pensadores e gestores da região.

Palavras-chave: América do Sul; Governança Costeira; Capacitação; Rede

\section{Introduction}

"Latin America" is a term with its roots in $19^{\text {th }}$ century French political writing that, against all odds, survives to this day and developed into something much larger than its initial political goals (see for instance the editorial of this issue).

Consequences of the common historical heritage, marked by the colonial influence, mainly from Spain and Portugal, are part of the identity of Latin American countries. This has, indeed, its highest expression in the use of common language, generalized to Spanish and Portuguese. Nevertheless, other nations left visible marks on their intent to conquer territories in this area, mainly Dutch, French and British, who never accepted the Tordesilhas Agreement, dividing Latin America between the two Iberian countries. As a consequence, despite the common background, the ecological, socioeconomic and cultural diversity are still remarkable, as well the diversity in the administrative political organization of the Latin American coastal regions. The geographical weight of Latin American countries is very marked, therefore, by its history but also for its physical geography, its population and economic issues.

The Central and South America correspond to a terrestrial area of more than 2 billion hectares, or $15,31 \%$ of the planet surface, not including the Exclusive Economic Zone (EEZs) or territorial seas. The population of this part of the word sums almost 600 million people, corresponding to $8 \%$ of the world population. Over $70 \%$ of the population of this region is concentrated in South America. It is worth pointing out Brazil, with
$35 \%$ of the population, followed by Mexico in Central America (21\%). However, the general population density of Brazil is very moderate $\left(23 \mathrm{hab} . / \mathrm{km}^{2}\right)$ compared to other Central American countries such as El Salvador (with $0.1 \%$ of the area of Latin America, has more than $\left.300 \mathrm{hab} . / \mathrm{km}^{2}\right)$ and Guatemala $\left(144 \mathrm{hab} . / \mathrm{km}^{2}\right)^{*}$.

Ten out of the fifteen most unequal countries in the world are in Latin America and the Caribbean, according to indices such as the Human Development Index or Gini Index. This should be highly considered in the regional priority initiatives tackling the use of natural resources and land management, especially in the coastal areas.

It is necessary to remind that the population of Latin America and the Caribbean is even more littoral than other areas. The region's coastal states have a full threequarters (more than 450 millions) living within 200 kilometres from the coastline. On South America's west coast 50 million people crowd along a thin coastal strips. In Chile, three-quarters of the population live and work along a $500 \mathrm{~km}$ stretch of coastline between Valparaiso and Concepcion, on $15 \%$ of the country's land area. And the east coast has also very dense areas, such as the Buenos Aires-La Plata-Montevideo region where14 million people live in. But the largest and most crowded coastal area by far is the highly urbanized

\footnotetext{
Figures derived from the data contained in the web page from the Department of Economic and Social Affairs, Population Division, from the United Nations [http://www.un.org/en/development/desa/ population/publications/database/index.shtml]
} 
region stretching from São Paulo to Rio de Janeiro, Brazil, with more than 40 million people (ArenasGranados, 2012; Hinrichsen, 1998).

As it is said in the Report of the Intergovernmental Panel on Climate Change (Magrin, 2007), significant impacts of climate change and sea level rise are expected for 2050-2080 on the Latin American coastal areas. It means ICZM is an urgent need to prevent lives and property losses.

The cultural and demographic diversity of this vast region leads to an equally rich diversity of conflicts on the coastal areas. Therefore a coastal and marine manager must face a multidisciplinary approach. Not forgetting the diversity of coastal ecosystems that support and coexist with urban agglomerations, infrastructures and industrial activities.

As some examples of those challenges, one can point out man-made and natural assets that make special cases of integrated coastal zone management (ICZM) needs, as for instance, Panama and Costa Rica.

Panamas' status as biogeographic region of transition between two continents permits an exceptional biodiversity, both terrestrial and marine. However Panama is also the bridge between two oceans, and this diversity must survive intense maritime traffic at the Panama Canal, through which pass about 14,000 ships per year and about $4 \%$ of world trade. The canal water basin, primary water source for the transit of vessels (each boat passing requires 52 million gallons of fresh water to cross the locks), provides $95 \%$ of the drinking water for the inhabitants' of the cities of Columbus, Panama and San Miguelito (Arenas, 2010).

Despite the high density of population of Costa Rica, this nation, which represents $0.04 \%$ of the planet's surface, accounts for $5 \%$ of the world's flora and fauna. Thus, leads to ambitious programs of conservation, with a strong commitment to ecotourism. Its National System of Conservation Areas (SINAC) covers the entire national territory, having $26 \%$ of its area protected under some category of conservation.

Not all Latin American countries border the sea, though. Paraguay and Bolivia are land-locked. However, the past and present needs for global integration made these countries look for solutions to their geographical position resulting in agreements with their fellow countries (Port of Ilo, in Peru, is used by Bolivia and Port of Paranaguá in Brazil by Paraguay). In addition their territories are integrated through the water catchment that drain to the coast, therefore the actions developed in those rivers (dams, etc.) tends to be reflected in coastal areas.

Some countries have taken off in their solutions to avoid and mitigate coastal conflicts. Both home-made and imported models are present in the continent.
Portugal and Spain, especially after their integration to the European Community, remain as fundamental examples and source of inspiration.

The academic community, which numerical contingent and level of development have a close relationship with the general economic and political scene, reflects through its bibliographic production the ideas and results of official choices and actions. Therefore, the representation of Latin American academic production regarding ICZM in a world scale is possibly a measure of our impact and influence over each other and beyond our cultural borders.

We have chosen to reflect the level of development of coastal management in Latin American countries through the number of the scientific publications related to this subject and to general issues at coastal areas, as well as through the capacity building programs existent in this region. Bibliometry measurements are frequently used to assess societal demands for knowledge about public and private investments. Recently (last decade), the pressure to publish hit Latin American universities hard. One of the response-trends identified was to report and discuss, face consistently collected and analysed data, the ICZM state of the art and its future.

The objective of this brief review is to quantify and discuss the bibliographical production of our academics and our capacity building programs as a proxy of the level of development of ICZM over the continent, including in the scenario Spain and Portugal.

\section{Results and discussion}

The Scopus database* was the only gateway used as the basis of the assessment. The main international journals accessible to every researcher around the world dedicated to coastal management were included. The indicators total number of papers published, timespan, number of papers attributed to Latin American countries, countries, timespan of papers attributed to Latin American countries and citation records were the variables chosen to develop the Results session. Papers published about Latina American countries, but prepared by authors based abroad were not considered at this time. Importance was given to works developed within the territories, by researchers directly exposed to its environments.

There are a large number of marine science journals, from many editorial houses, that publish papers dealing with coastal management issues, but not as their focus (e.g. Estuarine, Costal and Shelf Science, Marine Pollution Bulletin, Estuaries and Coasts). In these journals, there is a larger weight on papers about ecology, pollu

\footnotetext{
http://www.scopus.com
} 
tion and others as coastal processes. They have a strong, growing, generalist public among marine scientists as both readers and authors. The Journal of Integrated Coastal Zone Management (RGCI/JICZM) was not considered in this analysis because it covers a shorter time span, is bilingual, and is still in the process of building its first 3-years Impact Factor. In the same way, the new United Nations journal Costas was not taken into account.

Review papers are regarded as some of the most influential forms of academic expression and have therefore been highlighted here. Hopefully, a review paper will have a higher than average citation record, and therefore ideological influence.

The journals found most representative of the ICZM academic community and examined in this review were Ocean and Coastal Management, Coastal Management, Journal of Coastal Research and Journal of Coastal Conservation (Table 1). All these journals circulate for at least 30 years. These publications have been stable in terms of periodicity and have grown in volume along the years. They have also been published fully in English since their start, which facilitates access to authors from every nationality, although in Latin America, Spain and Portugal this has always been a more or less sored issue.

By order of numerical importance, Journal of Coastal Research (CERF) published until December 2014 a total of 4,725 documents (1985 to 2014), an average of 162.9 papers per year. Papers by Latin American based authors were 975 in total, and were published between 1992 and 2014. These works represent only $19 \%$ of the total papers published by the journal in its history. From those, 9 were review papers. The countries represented were, by order of importance, Portugal (316), Brazil (289), Spain (225), Mexico (65), Argentina (52), Colombia (15) and Chile (13).
Ocean and Coastal Management (Elsevier) published until December 2014 a total of 4,547 papers (1975 to 2014), which averaged a number of 116.5 papers per year. Papers by Latin American based authors were 393 in total, and were published from 1984 until present. These works represent only $8 \%$ of the total papers published by the journal in its history. From those, 22 were review papers. The countries represented were, by order of importance, Spain (114), Brazil (99), Mexico (89), Portugal (47), Chile (24) and Argentina (20).

The journal Coastal Management (Taylor \& Francis) published until December 2014 a total of 661 documents (from 1987 to 2014), which averaged a number of 24.5 papers per year. Papers by Latin American based authors produced 29 documents in total, which were published from 1997 until 2013. These works represent only $3.7 \%$ of the total papers published by the journal in its history. The countries represented were, by order of importance, Spain (15), Mexico (3), Portugal (3), Ecuador (2), Nicaragua (2), Argentina (2) and Brazil (2). From those, one was a review paper.

Springer publishes The Journal of Coastal Conservation since 1995 up to 2014. It has a total of 612 papers, being 93 from Spain, Portugal (72), Brazil (29), Mexico (51), Argentina (6), Colombia (1), summing 252 by Latin American based authors.

The most frequently represented countries, over this time spam, were the same in all four journals: Portugal (458), Spain (447) and Brazil (419), followed by Mexico, Argentina and Chile. Although Colombia, Nicaragua and Ecuador have also appeared in the assessment, these countries remain (together with all other Latin American countries) underrepresented in the international scene in relation to publications in the main ICZM discussion forums. Its is important to note that the Brazilian representation was expected to be one of the biggest due to its academic population and number

Table 1 - Identification characteristics of the studies journals, by order of impact factor.

Tabela 1 - Características identificadoras das revistas consideradas, por ordem dos fatores de impacto

\begin{tabular}{|c|c|c|c|c|c|c|}
\hline Source title & Editorial house & $\begin{array}{l}\text { Academic } \\
\text { background }\end{array}$ & $\begin{array}{l}\text { ISSN print } \\
\text { ISSN on line }\end{array}$ & $\begin{array}{l}\text { IF } 2013 \\
\text { (JCR) }\end{array}$ & Open access & $\begin{array}{c}\text { Base } \\
\text { country }\end{array}$ \\
\hline $\begin{array}{l}\text { Ocean and Coastal } \\
\text { Management }\end{array}$ & $\begin{array}{l}\text { Elsevier } \\
\text { commercial }\end{array}$ & $\begin{array}{l}\text { ECSA } \\
\text { IECS }\end{array}$ & 0964-5691 & 1.769 & $\begin{array}{l}\text { Partially } \\
\text { (authors choice) }\end{array}$ & $\begin{array}{l}\text { UK / } \\
\text { Netherlands }\end{array}$ \\
\hline Coastal Management & $\begin{array}{l}\text { Taylor \& Francis } \\
\text { commercial }\end{array}$ & $\begin{array}{l}\text { The Coastal } \\
\text { Society }\end{array}$ & $\begin{array}{l}0892-0753 \\
1521-0421\end{array}$ & 1.013 & No & US \\
\hline $\begin{array}{l}\text { Journal of Coastal } \\
\text { Research }\end{array}$ & $\begin{array}{l}\text { CERF } \\
\mathrm{NGO}\end{array}$ & CERF & $\begin{array}{l}0749-0208 \\
1551-5036\end{array}$ & 0.755 & $\begin{array}{l}\text { Partially } \\
\text { (authors choice) }\end{array}$ & US \\
\hline $\begin{array}{l}\text { Journal of Costal } \\
\text { Conservation }\end{array}$ & $\begin{array}{l}\text { Springer } \\
\text { commercial }\end{array}$ & EUCC & $\begin{array}{l}1400-0350 \\
1874-7841\end{array}$ & 1.096 & $\begin{array}{l}\text { Partially } \\
\text { (authors choice) }\end{array}$ & EU \\
\hline
\end{tabular}

ECSA - Estuarine Coastal Sciences Association / IECS - Institute of Estuarine and Coastal Studies / CERF - Coastal Education and Research

Foundation / EUCC - Coastal \& Marine Union, formerly called European Union for Coastal Conservation 
of researchers. Nevertheless, Brazil has a comparative low representation, in terms of length of coastline and papers, having around 5 published academic works per $100 \mathrm{Km}$ of coastline - considering a length of $8000 \mathrm{~km}$, against, for instance, to Portugal with 23 papers per 100 $\mathrm{km}$ of coastline $(2000 \mathrm{~km})$.

The performance of these journals regarding Latin American countries is a direct result of publication policies (special issues related to events, special issues focused on themes and advertisement). Interpersonal information among scientists also plays an important role. The academic production is still modest and books on ICZM published in Latin American countries are still rare. Text books or translations of English written texts are inexistent. Nevertheless it is worth of pointing out some important production in Spanish, as the brand new book Política, Gestión y Litoral: una nueva visión de la Gestión Integrada de Áreas Litorales, from Barragán (2014), currently being translated on to Portuguese. This book has a great potential to influence all Latin America countries.

The lack of a more extended academic production on ICZM ends up constraining the management of our coasts. There is a manifest need of capacity building programs in ICZM in Latin America in order to qualify academics and managers to implement an integrated and participative coastal zone management. Indeed the capacity building initiatives are growing in this region, despite its academic and natural science focus. According to Macías (2013) in recent decades there has been an increasing supply and demand for training in ICZM in Latin America. The author listed 18 postgraduate programs from different countries: Spain (9), Portugal (1), México (1), Costa Rica (1), Uruguay (1), Brazil (1) and two internationals (several countries). Recently a new master was approved in Argentina (Universidad de la Patagonia San Juan Bosco) dealing with tourism and coastal natural resources. Macías (2013) also demonstrated that most of the topics treated at the academic postgraduate courses related to ICZM are not directed related to management, but to natural/earth science or description of coastal dynamics and or pollution.

The trend of considering "Integrated" as a sum of disciplinary knowledge, not necessarily connected, is very present in capacity building initiatives and scientific production - even in the ones listed above. There is a repetitive misunderstanding between integrated / comprehensive approach and a multidisciplinary approach, where these disciplines, most of the time, do not interrelate to provide a holistic perspective. Students and/or managers are trained in specialized disciplines, barely touching specific issues related to the management process, such as leadership, management, decision making, organization, scheduling, planning, etc. This aspect, together with the lack of formal tools to integrate knowledge, will also reflect in a poor management of our coasts.

A training program designed for this purpose was TrainSeaCoast, the only UN-chancelled program implanted for local capacity building. However it is not running properly on the two locations in Latin America (South Brazil and Rio de la Plata region), not having any courses in the last years.

On other hand, an interesting instrument that has been having success and concrete results in areas such as training, education or publication on ICZM is the networks. These are generally presented as spaces for exchange and dissemination of knowledge, or a place for meeting and discuss the management of the coastal and marine environment. In many cases education and training activities are incorporated. In recent decades, these networks have proliferated especially in Iberoamerica including Portugal and Spain - both in academic and institutional level, related to the coasts and seas, ex.: CoPraNet, MedPan, NorBaff, Encora, CoastNet, IMCORE, REGIAL, Bencore, MARINET, ProPlayas, IBERMAR, WATERCLIMA-LAC, among others.

For instance, the "Red Iberoamericana de Manejo Costero Integrado - Red IBERMAR" was formed thinking on the integration existing among Latin American countries and Portugal and Spain. Since 2008 a group of countries organized themselves in a network for exchanging idea, philosophies and experiences on Integrated Coastal Zone Management (ICZM). The Network which was sponsored in its first Stage (20082012) by the Ibero-American Science and Technology Development (CYTED), now has the participation of over 250 researchers, teachers, public managers and members of ONG's that make up 15 national / state groups (Mexico, Honduras, Costa Rica, Panama, Cuba, Dominican Republic, Puerto Rico, Peru, Colombia, Chile, Argentina, Uruguay, Brazil, Portugal and Spain). By 2015 IBERMAR national groups in Ecuador and Venezuela will also be established. The network promotes a better approach between science and decision making, reducing the divergence that traditionally exists between scientific knowledge and integrated management (ecological, socioeconomic and cultural) of coastal marine governance.

WATERCLIMA-LAC is another important initiative currently taking shape, in line with the previous approach, particularly aimed at contributing to improving the management of watersheds and coastal areas to increase the resilience of Latin America and the Caribbean to the consequences of climate change. This will be a joint program that will run for three years from 2015, between the European Union and Latin America, based on the agreements reached in May 2008 in Lima during the V Summit between the European Union and Latin America and the Caribbean. 


\section{Conclusions}

An urgent effort to enhance ICZM is required in Latin America, including more academic production, capacity building programs and networks support. An integrated approach is also needed in order to achieve Integrated Coastal Zone Management, rather than a management of different activities and conflicts based on a sectorial approach.

The existing shortcomings of ICZM, which are reflected in academic production and capacity building programs also reveal the lack of government investment and of clear policies for the management of coastal areas. Also, the priority for publications given by the academics relegates the desirable work next to local,

\section{References}

Arenas-Granados, P. (2012) - Manejo costero integrado y sustentabilidad: Un análisis propositivo de políticas públicas en las dos caras atlânticas: España, Portugal, Colombia y Panama. 420p., Editorial Academica Española, Madrid, Spain. 'ISBN: 9783847354369. Available on-line at http://hum117.uca.es/grupogial/ paginas/publicaciones/libropedrodosmildoce

Barragán, J.M. (2014) - Política, Gestión y Litoral: Nueva visión de la gestión integrada de áreas litorales. 685p., Editora Tébar Flores, Madrid, Spain. ISBN: 978-8473605182. Partly available on-line at http://hum117.uca.es/grupogial/paginas/publicaciones/2014 _librounescobarragan

Hinrichsen, Don (1998) - Coastal Waters of the World: Trends, Threats, and Strategies. 298p., Island Press, Washington, DC, U.S.A. ISBN: 978-1559633833.

Magrin, G.; García, C.G; Choque, D.C.; Giménez, J.C.; Moreno, A.R.; Nagy, G.J.; Nobre C.; Villamizar, A. (2007) - Latin Amer- regional, national and international bodies to the second plan.

It seems that ICZM is still in its infancy in Latin America, as countries have apparently more pressing priorities to attend before thinking about coastal planning and conservation. Nevertheless, coastal planning and conservation might abate some of the socio-environmental and economic issues that plague Latin American countries, such as depletion of natural resources leading to poverty and natural disasters.

\section{Acknowledgements:}

We would like to acknowledge all collaborators of this review, especially the members of IBERAR network.

ica. In: M. L. Parry, O. F. Canziani, J. P. Palutikof, P. J. van der Linden \& C. E. Hanson (eds.), Climate Change 2007. Contribution of Working Group II to the Fourth Assessment. Report of the Intergovernmental Panel on Climate Change, pp.581-615, Cambridge University Press, Cambridge, U.K. Available on-line at http://www.ipcc.ch/publications_and_data/ar4/wg2/en/contents.html

Macías, Ana (2013) - La formación de los futuros gestores costeros: reflexión sobre los conceptos y principios básicos. In: J. A. C. Ruiz, J. G. Onetti, J. G. Sanabria, M. L. P. Cayeiro (eds.), Mejorando la Gestión de las Áreas Litorales de Iberoamérica. I Congreso Iberoamericano de Gestión Integrada de Áreas Litorales. Libro de Comunicaciones, pp.1685-1703, Grupo de Investigación Gestión Integrada de Áreas Litorales, Universidad de Cádiz, Cadiz, Spain. ISBN13: 978-8469512623. Available on-line at http://hum117.uca.es/grupogial/paginas/cursosymaster/icongresogia liberoamerica/comunicaciones-i-congreso-iberoamericano-de.pdf 